\title{
Feeds and feeding of livestock in Bangladesh: performance, constraints and options forward
}

\author{
KS Huque*, NR Sarker
}

Bangladesh Livestock Research Institute (BLRI), Savar, Dhaka 1341, Bangladesh

\begin{abstract}
Fibrous feeds mostly of crop residues, green grasses, and tree foliages and leaves support bulk diets of farm animals being raised mostly by smallholders. The roughage DM produced (51056 million $\mathrm{kg}$ ) surpasses its demand (49200 million $\mathrm{Kg}$ ) by $3.77 \%$, but losses and otherwise uses result in production deficit of $44.5 \%$. An average $56.2 \%$ deficit of roughage DM and $80.0 \%$ of concentrate DM results in a very poor plane of nutrition for farm animals. It supports an average diet containing 6.75 MJ ME/Kg DM and $1.63 \% \mathrm{DCP}$ with the feed produced or $7.74 \mathrm{MJ} \mathrm{ME} / \mathrm{Kg} \mathrm{DM}$ and $2.32 \% \mathrm{DCP}$ with the feed available, while a miserly calculation demands an average diet of at least $6.50 \mathrm{MJME} / \mathrm{Kg} \mathrm{DM}$ and $4.50 \%$ DCP. Brans and oilcakes sharing the bulk amount of concentrate feeds, except cereal maize being produced recently, often limit options for formulation of diets of higher metabolizability and quality protein including balancing of micronutrients essential for supporting nutritional planes for high yielding animals. Annual biomass demand and supply mismatch, harvest loss, bulk transfer problem, and otherwise uses of fibrous residues further limit feed supply to animals irrespective of their quality. Commercial poultry, on the other hand, is largely based on imported feeds except a part of corn. Different form of premixes, steroids, antibiotics and enzymes with or without knowing their quality and residual impacts on human health also used for poultry and bovine animals posing threats to food safety sometimes. The present poor plane of nutrition is not conducive to support an increased production of local or crossbred animals. Diversification and production of quality feeds and fodders, synchronization of feed production and availability to animals, strengthening feed milling capacity, conservation and improvement of new pasturage systems, mitigation of climate change impacts and domestic protection to feed safety and quality feed import are some of the options forward to increased supply of feeds and fodders help increased production and productivity of farm animals in the country.
\end{abstract}

Key words: Breed, feeds, livestock, nutrition

Bangladesh Animal Husbandry Association. All rights reserved.

Bang. J. Anim. Sci. 2014. 43 (1):1-10

\section{Introduction}

Bangladesh agriculture, sharing $19.95 \%$ of the gross domestic products (GDP) of the country (BBS 2011), has been transforming from traditional to input supported system followed by the post-independence green revolution in the country, challenging changing situations related to agro-ecology, socioeconomics and the climate. Tripling of rice production by escalating productivity using better genotypes and expanding agrarian capacity were keys to success of the green revolution. Livestock revolution for the developing countries predicted by the International Food Policy Research Institute in the late nineties is looming in the country through an average $26.0 \%$ growth of poultry meat and $29.1 \%$ of the egg of commercial chicken racing over some biological hurdles in the last decade. But, dairy or red meat production in the country, even after having an example of waving a magic wand in becoming recent global leader of milk production and meat export by India, is relaxing with an average growth of less than $2.0 \%$ (BBS 2011). However, limitation to agrarian capacity of the country in addition to emerging threats of sea level rise, climate change, and continuous change in rural farm holding (66.2\% of the total in 1996 vs $58.7 \%$ in 2008) or agri-labour household (35.9\% of the total in 1996 vs $34.4 \%$ in 2008 , BBS 2011) have been affecting livestock production in one hand, but on the other, rising population (1.59\%, BBS 2011), income and literacy growth, slowdown in income-induced demand for grains and dietary shift to higher 
value foods, and urbanization have been scaling up market demand of milk, meat and eggs. Comparison of food balance between 2005 and 2010 shows that per capita consumption of milk, meat, and egg in the country increased $4.0 \%$, $127 \%$ and $39.4 \%$, respectively (HIES, 2010). The per capita rice consumption, on the other hand, is decreased by $9.16 \%$ in the same period. All these substantiate livestock development to address food, more specifically, nutritional security of the growing population of the country by 2021 . Recent global food inflation and trade-offs between countries in the global market urge gaining of competitive advantages in domestic production and this requires another revolution to happen on modernization of agriculture including livestock production, that share $13.0 \%$ of the agricultural GDP (BBS 2011). This paper succinctly describe socio-economic contribution of livestock, status quo of its feeding and nutrition, constraints and options forward for increasing feeds and fodder availability in the country.

\section{Livestock production scenario}

The livestock consisting 25.8 million bovines, 17.3 million caprines and ovines and 135.1 million of poultry (BBS, 2012) contributes about US\$ 2309.0 million as animal farming GDP sharing 18.6, 56.3, 19.8, 2.68 and 2.64\%, respectively by dairy, meat, egg, hides and skin and others (BBS, 2011). It supported per capita intake of $14.3 \mathrm{~kg}$ milk, $8.90 \mathrm{~kg}$ meat and 115 eggs in 2011 (BBS 2012). The supply of milk and meat is only 15 to $20 \%$ of their annual requirement, and they are far below than that of the average of the developing countries $(55.0 \mathrm{~kg}$ and $32.0 \mathrm{~kg}$, respectively, Thornton 2010). The per capita annual egg consumption of the country in 2011 was 115 (BBS 2012) and the number is close to the average consumption of the developing countries (120 no).

Livestock is an asset of the rural poor, who suffers most from social disparity in nutrition and income. About $73.8,82.5$ and $82.7 \%$ of the total bovines, caprines and ovines and poultry, respectively are kept by the landless and small farmers (Agri Census 2008), and their annual population growth was $3.98 \%, 3.1 \%$ and $54.8 \%$, respectively during the period of the Agricultural and livestock Census 1983/84 to Agriculture Census 2008. The average share of the same animals by the medium and large farmers, on the other hand, was 26.2, 17.5 and $17.3 \%$, respectively, (Agri Census 2008). The average annual population growth of the former two groups of ruminants was -1.98 and $-2.0 \%$, respectively and that of the poultry was $15.0 \%$. Thus, the key performance indicator of livestock production being an asset of the rural poor is not only food production, but raising rural income, women employment and poverty alleviation are also their significant contribution to socioeconomic development. Farmers having an average two milking cows in an average herd of 4.43 annually spend about US\$ 1000.0 out of his total annual income of US\$1520.0 including US $\$ 825.0$ from milk and animal sales, and daily make 0.85 litres milk available to his/her family or rear a flock of 250 layers earn annually US\$ 1170.0 or fatten a bull may earn US $\$ 60.0$ to 325.0 depending on its procurement price (Huque et al. 2009).

\section{Genotypic share and trend in productivity}

The relative importance of cattle in dairy is about $98 \%$ and buffalo milk shares only $2 \%$ (The country report on FAnGR 2005). Fowl and ducks share $76 \%$ and $24 \%$ of the total egg production, and the two genotypes share $54 \%$ of the total meat produced in the country. Bovines share $40 \%$ of the total red meat production and the rest $6 \%$ is shared by chevon and mutton. During the period of 1996 to 2011 liquid milk production increased from $1552.0 \times 10^{3}$ to $1868 \times 10^{3}$ tons and around $13 \%$ liquid milk equivalent powder milk is imported every year, and the import is rising during the last decade. Inclusion of quality genes over the past decades through crossbreeding of cattle annually increased liquid milk production at the rate of only $1.17 \%$. Similarly, bovine meat production increased from $325 \times 10^{3}$ to $413 \times 10^{3}$ tons and had a growth of $1.36 \%$ in the same period (BBS 2011). The production of chevon and mutton remains almost constant. Nevertheless, commercial poultry fed with mixed feed manufactured in local mills using mostly imported feed ingredients except a part of cereal maize, resulted in $29.1 \%$ growth of egg (2776 to 17177 million) and $26.0 \%$ growth of poultry meat $\left(138.6 \times 10^{3}\right.$ to $580.4 \times 10^{3}$ tons, respectively (BBS 2011). However, the growing population has continuously been influencing the per capita availability of animal products. HIES (2010) shows that the daily per capita bovine meat 
consumption was $8.30 \mathrm{~g}$ in 2000 and $6.84 \mathrm{~g}$ in 2010 , that of caprine and ovine meat was $0.49 \mathrm{~g}$ and $0.60 \mathrm{~g}$, respectively, and of poultry meat was $4.50 \mathrm{~g}$ and $11.2 \mathrm{~g}$, respectively. When per capita average bovine number is gradually decreasing, the market price of bovine meat is increasing during the period (US\$ $1.29 / \mathrm{kg}$ in 2001 to US\$ $2.87 / \mathrm{kg}$ in 2011). The present beef price in the local market has already exceeded the price of some beef exporting country in the world. The growing demand and price escalation of beef will definitely welcome a situation, like that of milk import. Import of meat and milk may be a consolation for affluent peoples of the society that deprives livelihood opportunity of the rural poor. Production and marketing of a ton of liquid milk may support livelihood of at least 30 rural farm families in the country (Huque 2005). Thus, any strategic development of dairy and meat will definitely increase not only products but also help alleviation of income and nutrition disparity of the country. The average yield of bovine carcass weight in the country is only $72 \mathrm{Kg} / \mathrm{head}$. An advancement of about only $2.85 \%$ was observed during the period of 2000 to 2006 (Huque and Amanullah 2006), and replenishing of depleted cattle of low plane of nutrition or of draft use through fattening help boosting the carcass yield.

Rural dairy, of the three classified dairy system (rural, peri-urban and structured market, Huque, 2005), contributes $68 \%$ of the total liquid milk production in the country. An average rural dairy in the selected area having an average herd size of 1.3 produces $1.20 \mathrm{Kg} \mathrm{milk/cow}$, and a crossbred cow, having support of better feeding and nutrition in a structured market area produces $9.80 \mathrm{Kg}$ milk/head daily (Table 1 ). Scarce input and irregular or absence of market support limit increased production and productivity of milk in the country, and year round availability of quality feeds and fodder may play a significant role.

Table1. Dairy production system, cow/herd and average milk yield (Huque 2005)

\begin{tabular}{lcc}
\hline Production systems & Cow/herd & Kg milk/cow \\
\hline Rural & 1.30 & 1.20 \\
Peri-urban & 4.79 & 3.55 \\
Structured market dairy & 7.00 & 9.80 \\
\hline
\end{tabular}

Besides, intensive productions with better genotypes and higher planes of nutrition may help boosting milk and meat production in the country. This will help livelihood development of the farmers.

\section{Bangladesh share of global manufactured feed market}

Continuous change of agro-ecosystem and climate along with agrarian transitions in Bangladesh require dynamic approaches in better understanding of feeds and fodder production in terms of land use, production of cereal crops and plantations and their economic use for production of animal source foods profitably minimizing negative impacts on the environment as a whole. Concentrate feeds are still a driving force to increase productivity of farm animals, but optimization of rumen fermentation system of fibrous feeds may play a significant role on the increase of productivity minimizing gas emissions and reduction of concentrate feeds. The developing countries using 240.0 million ton of concentrate produced 170 million tons of milk, meat and eggs in 1980 and it multiplied the food production increasing concentrate use to a similar extent over the years. A giant user of concentrate in the Asia is China, it produces 198.3 million ton (20.78\%) of concentrate feed out of the global total of 954.0 million ton, of which 636.0 million tons $(66.7 \%)$ is used for poultry and pigs and 253.0 million tons $(26.5 \%)$ is used for ruminants (Alltech 2013). The USA is the second largest producer with the annual production of 168.5 million ton $(17.66 \%)$ and India is on the rise of production reflecting annual total production of 26.8 million ton (Alltech 2013). Bangladesh produces only 2.73 million ton (Alltech 2013), and most of the feed is used for commercial poultry production in the country leaving native chicken and duck production on scavenging feeds. The native chicken and ducks, allowing supplementary feed of daily $50 \mathrm{~g}$ and $100 \mathrm{~g} / \mathrm{head}$, respectively; may require annually an estimated amount of 5.94 million ton. The potentiality of native poultry and ducks on meat and egg production still remains unearthed.

\section{Domestic feed production and availability to ruminants}

The ruminant animal in the country is mostly raised on fibrous crop-residues and cereal milling by-products. The total roughage production in the country is estimated to be $51056 \times 10^{3}$ ton in 2012 , of which $5781 \times 10^{3}$ ton comes from cut and 


\section{Livestock feeds and feeding}

carry and road side grazing (considering daily availability of $1.0 \mathrm{Kg}$ green grass per head). This results in a ratio of 89:11 for fibrous residues of crop to green biomass. About $27316 \times 10^{3}$ ton $(53.5 \%)$ of the fibrous biomass produced in the country is available to animals as feed, and the rest bulk is gone off, and used otherwise. Cereal milling by-products, grains and oilcakes are the three major types of ingredients constitute concentrate feed in the country. Based on the extraction rates of by-products of different cereals shown by Huque and Amanullah (2009), the annual availability of the three types concentrate is about $2916 \times 10^{3}$ ton $(58.0 \%)$, $2042 \times 10^{3}$ ton $(40.6 \%)$ and $67.6 \times 10^{3}$ ton $(1.34 \%)$, respectively (Table 2 ).

The country produces around $72.0 \times 10^{3}$ ton of molasses every year, and a major part of it is exported and used for ethanol production locally. A country having about $80 \%$ deficit in the production and availability of concentrate feeds may not spare any part of such an effective cattle feed for the export. Methane, a major component of green house gas, produced in the rumen at the expense of up to $15 \%$ of the dietary digestible energy when it lacks supplementation of protein and soluble carbohydrate. It may be reduced up to $30 \%$ when rice straw diet is supplemented with urea and molasses (Huque and Chowdhury 1997). Thus, molasses in addition to its contribution to farm animal production also help mitigation of environment pollution. A strategic plan to make molasses available to farmers cost effectively without any participation of middlemen, that, in addition to export, often make molasses unreachable by the farmers is essential.

The country produces $6.54 .0 \times 10^{3}$ ton of cotton seed cake and around $96.5 .0 \times 10^{3}$ ton of fruit and vegetable wastes (Table 2 ). All these feeds may effectively be used for premixed feed production.

Table 2. Dynamics of feeds and fodder resources and their annual production (BBS 2012)

\begin{tabular}{|c|c|c|c|c|c|c|c|c|}
\hline \multirow[t]{2}{*}{ Crops } & \multirow{2}{*}{$\begin{array}{l}\text { Annual cereal } \\
\text { yield (x103 ton) }\end{array}$} & \multicolumn{4}{|c|}{ Fibrous crop residue production ( $\times 10^{3}$ ton) } & \multicolumn{3}{|c|}{ Cereal by-products (x103 ton) } \\
\hline & & Types & Fresh & Dry matter & Availability & Types & Production & Availability \\
\hline Rice & $\begin{array}{c}34430.0 \text { (BER, } \\
2013)\end{array}$ & Straw & 44759.0 & 40283.0 & $\begin{array}{c}20141.5 \\
(50 \%)\end{array}$ & Bran & 2754.0 & 2754.0 \\
\hline Maize & $\begin{array}{c}2042.0 \text { (BER, } \\
2013)\end{array}$ & Stover & 4084.0 & 2042.0 & $204.2(10 \%)$ & $\begin{array}{l}\text { Corn } \\
\text { Bran }\end{array}$ & $\begin{array}{c}2042.0 \\
163.4\end{array}$ & $\begin{array}{c}2042.0 \\
72.0\end{array}$ \\
\hline Wheat & $\begin{array}{c}1036.0(\mathrm{BER}, \\
2013)\end{array}$ & Straw & 1036.0 & 932.0 & $9.32(10 \%)$ & $\begin{array}{c}\text { Wheat } \\
\text { bran }\end{array}$ & 82.9 & 82.9 \\
\hline Minor cereals & 0.97 & Straw & 3.80 & 3.49 & - & - & - & - \\
\hline Pulses & 232.0 & Offal & 928.0 & 835.0 & $\begin{array}{c}835.0 \\
(100 \%)\end{array}$ & Bran & 6.96 & 6.96 \\
\hline Sesame & 31.0 & \multicolumn{4}{|c|}{$70 \%$ of seed wt. is cake } & Oilcake & 25.1 & 25.1 \\
\hline Rape and Mustard & 246.0 & \multicolumn{4}{|c|}{$70 \%$ of seed wt. is cake } & Oilcake & 18.2 & 18.2 \\
\hline Ground nut & 54.0 & \multicolumn{4}{|c|}{$50 \%$ is used for oil, $75 \%$ is seed wt., $55 \%$ of seed wt is cake } & Oilcake & 14.8 & 14.8 \\
\hline Coconut & 326.0 & \multicolumn{4}{|c|}{ Copra- $6.0 \%$, meal- $30 \%$ of copra, consider $50 \%$ is crushed) } & Oilcake & 2.93 & 2.93 \\
\hline Cotton & 5.90 & \multicolumn{4}{|c|}{ Seed wt. is 1.45 times, $85 \%$ is cake) } & Oilcake & 7.37 & 6.50 \\
\hline \multirow{2}{*}{ Sugarcane } & \multirow{2}{*}{4670.0} & Tops & 934.0 & 373.0 & $74.6(20 \%)$ & \multirow{2}{*}{ Molasses } & \multirow{2}{*}{72} & \multirow{2}{*}{-} \\
\hline & & Leaves & 467.0 & 210.0 & $210.0(100 \%)$ & & & \\
\hline Potato & 8326 & Plants & 1665.0 & 499.0 & $49.9(10 \%)$ & - & - & - \\
\hline $\begin{array}{l}\text { Mango, Pineapple, } \\
\text { Banana and } \\
\text { Jackfruits }\end{array}$ & 2871.0 & Waste & 630.9 & 93.83 & 9.38 & - & - & - \\
\hline Mulberry & 14.0 & Leaves & 1.40 & 0.56 & 0.27 & - & - & - \\
\hline Vegetable & 10516.0 & Waste & 2629.0 & 2.63 & 0.65 & - & - & - \\
\hline $\begin{array}{l}\text { Green grasses } \\
(1.0 \mathrm{Kg} / \mathrm{head} / \mathrm{day})\end{array}$ & - & $\begin{array}{l}\text { Green } \\
\text { fodder }\end{array}$ & 19272 & 5781.6 & 5781.0 & - & - & - \\
\hline Total p & uction & & & 51056 & 27316 & - & 5189.7 & 5025.4 \\
\hline
\end{tabular}




\section{Plane of nutrition of farm animals}

The existing population of different ruminant animals according to their age and sex available in the country was converted into livestock units of a constant weight, and the requirement of dry matter (DM) was calculated considering daily 3.0 $\mathrm{Kg} \mathrm{DM}$ for each $100 \mathrm{~kg}$ live weight. It shows that the country requires 73800.0 million $\mathrm{Kg}$ total dry matter (DM) annually to feed existing ruminant animals. An average ruminant diet sharing roughage and concentrate DM at a ratio of $2: 1$ will make a total demand of $49200 \times 10^{3}$ ton and $24608 \times 10^{3}$ ton, respectively of the two feeds. The total annual roughage DM production is $51056 \times 10^{3}$ ton surpassing by $3.77 \%$ of its total annual demand. But, its annual availability to animal is $27316 \times 10^{3}$ ton (Table 2 ). This results in a deficit of $56.2 \%$ of the total demand (Table 3 ). The most important factor is the miss-match of production and supply of the biomass. Most of the fibrous residues is produced in the monsoon, when sun drying, the lone system for preservation of crop residues, is difficult and farmers fail to make them available for their animals in dry season. Collection, processing and preservation of fibrous crop residues and their value addition may increase their availability to animals.

Table 3. Demand, production and availability of DM of feeds and fodder for the ruminant animal of Bangladesh in 2011

\begin{tabular}{lccc}
\hline Items & Total & Roughage & Concentrate \\
\hline Demand (Million kg DM) & 73800 & 49200 & 24608 \\
Production (Million Kg DM) & 56081 & 51056 & 5189.7 \\
Deficit (\% of demand) & -20.3 & 3.77 & -79.0 \\
Available (Million Kg DM) & 32341.0 & 27316 & 5025.4 \\
Availability (\% of Production) & 57.7 & 53.5 & 96.8 \\
Deficit ( \% of demand) & $56.2 \%$ & $44.5 \%$ & $79.6 \%$ \\
\hline
\end{tabular}

DM, dry matter

The demand and supply situation of concentrate feed is very poor in the country. The total demand is met only $19.4 \%$ by its annual availability of $5025.4 \times 10^{3}$ ton, and a very negligible amount ( $164.2 \times 10^{3}$ ton) is used otherwise. The country introduced corn production in the late eighties and it becomes successful in producing a major share of corn required to support the poultry industries in the country. Similarly, production and productivity increase of pulse and oil crops will reduce import and increase concentrate feed supply in the country. A coordinated strategic legume and oil crop production and their by-product use as feed may help alleviate feed shortage.

The average dietary concentration of metabolizable energy (MJ ME/kg DM) per kilo DM and digestible crude protein (DCP, \%DM) of ruminants varies due mainly to age, sex, physiological stage and production. An average mixed diet for ruminant animals other than calves may contain 7.5 to $11.0 \mathrm{MJ} \mathrm{ME} / \mathrm{Kg} \mathrm{DM}$ and 3.5 to $11.0 \%$ DCP (BSTI, 2008). The calculation of nutrient (MJ ME and DCP) requirement of existing farm animals in the country was done following a similar method used for calculation of dry matter requirement. The total demand of MJME and DCP was calculated following the Livestock Feed Standard of Bangladesh Standard and Testing Institute (BSTI 2008).

Table 4. Demand, production and availability of energy (MJME) and DCP for the ruminant animal of Bangladesh

\begin{tabular}{lcc}
\hline Items & MJME/year & Kg DCP/year \\
\hline Demand (Million) & 457265.0 & 3332.0 \\
Production (Million) & 397224.8 & 959.8 \\
Production deficit, \% of demand & -13.13 & -71.2 \\
Available (Million) & 250217.0 & 748.9 \\
Availability, \% of production & 63.0 & 78.0 \\
Availability, \% of demand & 54.7 & 22.5 \\
\hline
\end{tabular}

$\mathrm{DCP}$, digestible crude protein

The total annual demand of million MJME and million $\mathrm{Kg}$ DCP for the existing ruminant animals is calculated to be 457265.0 and 3332.0 , respectively, and the production from the feed produced in the country is 397224.8 million MJ ME and 959.8 million $\mathrm{Kg} \mathrm{DCP}$, respectively. This shows production deficit of $13.13 \%$ and $71.2 \%$, respectively the two nutrients. Considering feed availability about 250217.0 million MJME and 748.9 million $\mathrm{Kg}$ DCP are available to animals. The availability of the two nutrients is low and it is found to be $63 \%$ and $78 \%$, respectively compared to production, and $54.7 \%$ and $22.5 \%$, respectively compared to their demand (Table 4 ).

Table 5. Composition of target diet for ruminant farm animals and diet of feed produced or available

\begin{tabular}{lccc}
\hline \multirow{2}{*}{ Items } & \multicolumn{3}{c}{ Average dietary composition } \\
\cline { 2 - 4 } & Target diet & Feed produced & Feed available \\
\hline MJME/Kg DM & 6.20 & 6.75 & 7.74 \\
DCP \% & 4.51 & 1.63 & 2.32 \\
\hline
\end{tabular}

DM, dry matter; DCP, digestible crude protein 
The plane of nutrition on which the ruminant animals are raised is reflected further by the calculated average diet using the feed produced or the feed available to animals (Table5). Compared to a target diet containing 6.20 $\mathrm{MJ} \mathrm{ME} / \mathrm{KgDM}$ and $4.51 \% \mathrm{DCP}$ an average diet of feed produced contains 6.75 MJME/Kg DM and $1.63 \%$ DCP or an average diet of feed available contains $7.74 \mathrm{MJME} / \mathrm{Kg}$ DM and $2.32 \% \mathrm{DCP}$ (Table 5). The feed availability data (Table 2) shows that about $89 \%$ of the roughage produced or available is fibrous crop residues that contain negligible amount (average 2.0\%; Feedipedia, FAO) of DCP and the rest $11 \%$ is green biomass. The concentrate production or availability, on the other hand, is far below than the animal requires, and the deficit is $79.8 \%$ compared to its demand. Similarly, DCP production deficiency is $71.2 \%$, and only $22.5 \%$ of the demand is available (Table 4). This has been reflected in the calculated average diet of feed produced or feed available.

\section{Feed manufacturing, marketing and quality control}

Bangladesh produces about 2.73 million ton of manufactured feed (Alltech 2013) annually both for poultry and ruminant animals in addition to on-farm feed availability. Feed manufacturers collect local and exotic feed ingredients and add values to market them locally. About 2395.2 tons of vitamin and mineral premixes and 72.8 tons of steroids, enzymes and antibiotics etc. are marketed as growth promoters annually for feeding ruminant animals (Khan 2010). About $12 \%$ of these growth promoters is imported, $38 \%$ is imported but premixed further locally and $50 \%$ is manufactured locally (Khan 2010). Farmers being educated by the marketing organization procure and use these growth promoters without knowing its impact on animal or human health. However, this growth of feed industry may be encouraged further regulating product quality to ensure food safety.

\section{Challenges for feeds and fodder production}

i. I ncreased availability of protein rich feeds and fodder: As stated above quantitative deficiency of digestible crude protein (DCP) is a major threat for farm animal production in the country. Options for increased production and supply of high quality protein feeds and fodder should be explored. Expansion of pulse and oil seed crops will definitely help increased production of food and feed. Moreover, potential plantation crops may be identified and brought into production system for commercial production of high quality feed following the existing social plantation system.

ii. Synchronization of domestic feed production and availability: This requires on-farm adoption of available technology on processing and preservation of fibrous feeds through strengthening public and private sector extension activities. Moreover, value addition to biomass produced in different seasons and marketing cost effectively may in one hand, help expansion of feed industry, and on the other, make premixed feed available to farmer, when and where their support requires.

iii. Population growth, land disappearance and food and feed competition: Land use for food or feed production, a debate everywhere, when the population is growing and it is expecting to reach at 231.0 million in 2050. This confusion is unnecessarily affecting human rights to food, more specifically nutrition security to all. Feed is converted to quality food for human by farm animals, and without better nutrition of livestock human nutrition may not be secured. Moreover, national income and nutritional disparity may not be addressed without developing livestock a major part of it is kept by the rural poor of the country. This requires judicial use of land devising cropping systems that allow food and feed production sustainably and economically.

iv. Climate change: Bangladesh is poised to lose a good part of its territory in the south for sea level rise and intrusion of saline water, and further, existing cropping system is always being threatened by the change of climate and pollution of environment. This is definitely affecting feed biomass production quantitatively and qualitatively. This requires dynamic strategies to mitigate climatic impacts and planning further for food and feed production using available land and plant biodiversity. 
v. Relaxed scientific and technological endeavour: A world food prize-2013 giving ceremony in the USA observed that scientific advancement will play a critical role to face global challenges for more food production, and the US secretary John Kerry added that through innovation, we can help alleviate hunger and malnutrition today-but more than that, we can help fulfil our responsibility to tomorrow. Following the philosophical maxims we may state that we need some food visionaries who can revolutionize modern agriculture through dynamic scientific and technological endeavours rather than relaxing in the existing enraged research environment in the country. A dazzling research environment would allow strategic use of feed science and technology along with frontier scientific breakthrough taping recent advances in genomics, proteomics transcriptomics and metabolomics. This would help the farm animals of the country to have better nutrition and feeding for supporting our food security.

\section{Options forward}

\section{i. Diversification and production of quality feeds and fodders}

Diversification and production of quality feeds and fodders, that are of high metabolizability and balance of macro and micro nutrients and that support animal productions cost effectively without any threats to human health, including adoption of their value addition technologies are important for achieving economically sustainable animal production systems. In addition to increasing dual purpose crop introduction in the existing cultivation system potential of plantation crops, in a tropical country like Bangladesh, as animal feeds may be explored. This is largely unknown, their exploration and use requires intensive efforts of science and technology. Any effort that i) explores quality feeds and fodders ii) generate production technologies for making their biomass available using agro-ecosystem sustainably and economically, and iii) add value addition technologies for production and marketing of cost effective premixed feeds using the biomass may boost milk and meat production in the country. Moringa Oliefera could be one of the best options, the foliage of which may replace concentrate in the diet of farm animals.

Moringa grows in a diverse soil and climatic condition, especially on homesteads, roadsides with little agronomic care, is raised mainly for using their drumsticks or to some extent leaves as vegetable. It may be propagated both sexually and asexually and pruned in every 40 to 45 days in optimum soil condition, and may yield 580.0 ton fresh or 99.0 ton dry matter, if 1.0 million plants per hectare is cultivated and harvested nine times/year and this practise may continue even up to 4 years (Foidl et al., 2001). Moringa leaves contain 26.4 to $29.0 \%$ crude protein with an average rumen degradability of $48.6 \%$ and have post-rumen digestibility of $47 \%$ (Makkar and Becker, 1996). Compared to other plant protein, such as soybean; a higher fraction of Moringa leaf protein bypasses the rumen degradation. It contains all essential amino acids including lysine and methionine in adequate concentration (Zarkadas et al. 1995), 0.63\% calcium which is more than ten times higher than the level of phosphorus $(0.05 \%$, Gidamis et al. 2003), and $5.0 \%$ saponin (Makkar and Becker 1996), that helps rumen defaunation. Moringa foliage, on the other hand, containing 1.7:1 leaf to stem ratio and $21.0 \%$ crude protein is $77 \%$ digestible in goats (Sultana et al. 2012), and may replace concentrate mixed feed of $18.4 \%$ crude protein and 9.98 MJ ME per kg DM or its dietary inclusion at $25 \%$ of a Napier diet for goats may yield double growth (Sultana et al. 2012). It may yield daily $300 \mathrm{~g}$ more live weight in fattening cattle (Foidl et al. 1999) or $60 \%$ more milk when daily fresh foliage supplementation was @3.0KgDM/cow (Sanchez et al. 2006). All these data show that Moringa foliage is superior in nutritional values (contains $21.0 \%$ protein, 9.5 MJ ME/Kg DM, and 74\% digestible organic matter) to Alfalfa (Medicago sativa), the queen of forage crops $(18.0 \%, 8.50 \mathrm{MJME} / \mathrm{Kg} \mathrm{DM}$ and $63.0 \%$, Heuzév et al. 2013) and its yield per hectare is more than twelve times than the later (99.0 ton vs 8.0 tone DM). 


\section{Livestock feeds and feeding}

Table 6. Biomass production, unit cost and average nutritional weights to farm animals of different feeds and fodders (Based on authors calculation)

\begin{tabular}{|c|c|c|c|c|c|}
\hline $\begin{array}{l}\text { Sl. } \\
\text { No. }\end{array}$ & Fodder & $\begin{array}{l}\text { Average annual biomass } \\
\text { production/hectare }\end{array}$ & $\begin{array}{l}\text { Predicted production cost, } \\
\text { US\$ per ton DM }\end{array}$ & $\begin{array}{l}\text { Predicted nutritional weight } \\
\text { to animals based on DOM }\end{array}$ & Remarks \\
\hline 1 & $\begin{array}{l}\text { Napier (Pennicum } \\
\text { maximum) }\end{array}$ & Fresh-200 tons, DM-50 tons & 150.0 & 0.81 & \multirow{5}{*}{$\begin{array}{l}\text { Animal production } \\
\text { response factors o } \\
\text { feeds are not } \\
\text { considered }\end{array}$} \\
\hline 2 & Maize (Zea mays) & Fresh-50.0 tons, DM- 15.0 ton & 420.0 & 1.00 & \\
\hline 3 & Moringa Oleifera & $\begin{array}{l}\text { Fresh-580.0 tons, DM-99.0 } \\
\text { tons (Makkar, 2013) }\end{array}$ & 294.0 & 1.35 & \\
\hline 4 & $\begin{array}{l}\text { Mixed concentrate } \\
\text { feed }\end{array}$ & - & 486.0 & 1.27 & \\
\hline 5 & Alfalfa & Fresh-20.0 ton, DM- 6.0 ton & 240.0 & 1.31 & \\
\hline
\end{tabular}

DM, dry matter; DOM, digestible organic matter

Moringa may not compete for land or make any conflict with rice cultivation, as the later is water loging crop and the former is sensitive to stagnant water. Table 6 shows estimated comparative production cost and average nutritional weights of different fodder crops to farm animals. Considering predicted nutritional weight to farm animals (considering 1.0 for Maize) and unit DM production cost, Moringa foliage having a higher nutritional weight is comparatively cheaper and most nutritional feed for farm animals. It may support commercial protein meal production in the country, and if produced and processed sustainably and economically, and may reduce import of premixed feeds. It may require social enterprise development for supporting bulk production denying question of land unavailability and for processing and marketing of Moringa protein meal. Having open regulatory restriction to smoking, the country allows 120,000 acres of cultivable land for tobacco production, when everyday $1.70 \%$ of the cultivable land has been disappearing. Considering supplementary impacts on fresh milk or lamb production reported by Mendieta et al. (2007) it may be calculated that supplementation of Moringa foliage biomass from one acre of land may produce 35.3 tons more milk or 7.48 tons of more lamb; while tobacco production is only 0.66 ton/acre. However, the challenges on the development of cost effective production system comparing with competing crops and matching with changing agrarian practices and adoptions of value addition technologies require immediate research thrusts for using Moringa as a fodder crop. Similar perennial plantation crops or any other crop like Lathyrus sativus, Vigna mungo having high nutritional value to ruminants may be searched and used judicially.

\section{Strengthening feed milling capacity}

Besides better use of on-farm fibrous crop residues surplus biomass may be collected and processed for pre-mixed/densified feed production and marketing. This, minimizing nonsynchronization of feed production and use, will make quality feed available to farmers and help boosting production, and at the same time feed industries will grow further. This requires strong commitment of private sector under capital and regulatory frame work support of the public sector. One of the best cattle feed in the country is molasses, that, even after ethanol production, may be supplied to feed industries for premixed/densified feed production for ruminant animals. The problem of pre-mixed/densified fibrous feed preservation in a humid country like Bangladesh may easily be overcome using chemical preservatives to be imported. This may provide an opportunity for best utilization of fibrous crop residues produced in the country. Problem of bulk transfer of fibrous crop residues from cropping area to livestock production area will also be minimized.

\section{ii. Conservation and improvement of new pasturage productions in emerging lands}

Baghabari Bathan is the only pasturage production system (conserving common grazing land and allowing farmer's animal to graze) exists in the country. Similar systems may be conserved and improved in the delta areas of the country. Existing Buffalo or Sheep productions in 
the south delta may easily be turned into pasturage production system.

\section{iii. Domestic protection to feed import and quality control}

The government has been giving tax holidays to feed/feed ingredient import. A strong monitoring and evaluation should have to be in place on the evaluation of farmers' benefit out of it. A huge amount of feed additives or their ingredients is being imported in premixed form or after the import they are manipulated locally and marketed without knowing their impacts on production and productivity increase of farm animals. The import under the tax holiday, after a thorough review, should have to be directed to support increased feed milling in the country.

In conclusion it may be succinctly stated that the existing production and growth of milk and meat is not sufficient to meet present and growing demand, and a slower growth of global agriculture in coming decades as predicted may affect vision of food security of the country. Production and productivity increase, in addition to inclusion of quality genes into farm animals, requires support of quality nutrition, more specifically protein rich feeds and fodders, which is lacking in the country. The present poor plane of nutrition is not conducive to support increased production of local or crossbred farm animals. Production of protein rich feeds and fodder crops, synchronization of production and availability of feed to farmers, and mitigation of climate change and environment pollution are the challenging factors, which require strategic use of feed science and technology along with frontier scientific advances. Diversification and production of quality feeds and fodders, strengthening feed milling capacity, conservation and improvement of new pasturage systems and domestic protection to feed import and quality control are some of the options forward to upgrade feeds and feeding plane of farm animals in the country.

\section{References}

Agriculture and Livestock Census (1983/84). In: Statistical Year Book of Bangladesh 1991, Statistics Division, Ministry of Planning, the Govt. of Bangladesh.

Alltech (2013). Global feed summary; www. alltech.com
BBS (Bangladesh Bureau of Statistics) (2011). Statistical Year Book of Bangladesh, Statistics Division, Ministry of Planning, The Government of peoples Republic of Bangladesh.

BBS (Bangladesh Bureau of Statistics) (2012). Statistical Year Book of Bangladesh, Statistics Division, Ministry of Planning, The Government of peoples Republic of Bangladesh.

BER (2013). Bangladesh Economic Review; Economic Adviser's Wing; Finance Division, Ministry of Finance, The Government of peoples Republic of Bangladesh.

BSTI (Bangladesh Standard Testing Institute) (2008). Specification for Feeds and Feeding of Farm Animal and Pets, Bangladesh Standard and Testing Institute, BDS 1804: 2008; 116/A, Tegaon, Dhaka 1208, Bangladesh.

Census of Agriculture (2008). Structure of Agricultural Holdings and Livestock Population National Series Volume 1; Bangladesh Bureau of Statistics, Statistics Division, Ministry of Planning, The Government of peoples Republic of Bangladesh.

Country Report of FAnGR (2005). The Government of peoples Republic of Bangladesh.

FAO (Food and Agriculture Organization) (2006). World agriculture: towards 2030/2050. Interim report, global perspective studies unit, Rome Italy: Food and Agriculture Organization of the United Nations.

Feedipedia; www.feedipedia.orgl; FAO, INRA, CIRAD and AFZ.

Foidl N, Makkar HPS, Becker K (2001). The potential of Moringa oleifera for agricultural and industrial uses. In: "The Miracle TreeThe Multiple Attributes of Moringa." (Ed. Lowell J Fuglie). CTA Publication. Wageningen, The Netherlands.

Foidl N, Mayorga L, Vásquez W (1999). Utilización del Marango (Moringa oleifera) como forraje fresco para el Ganado. Conf. Electrónica de la FAO sobre Agrofor. Para la Prod. Anim. en América Latina. www.fao.org/livestoc/agap/frg/agrofor $1 /$ foi dl16.htm.

Gidamis A, Panga J, Sarwatt S, Chove B, Shayo N (2003). Nutrient and antinutrient contents 


\section{Livestock feeds and feeding}

in raw and cooked leaves and mature pods of Moringa oleifera Lam. Ecol. Food and Nutrition. 42, 1-13.

Heuzé V, Tran G, Boval M, Lebas F, Lessire $M$, Noblet J, Renaudeau D (2013). Alfalfa (Medicago sativa). Feediedia.org. A programme by INRA, CIRD, AFZ and FAO.

HIES (2010). Household Income and Expenditure Survey 2010; In. Statistical Year Book of Bangladesh 2011, Statistics Division, Ministry of Planning, The Government of peoples Republic of Bangladesh.

Huque KS, Amanullah SM (2009). Conservation, seed multiplication and fodder production; The paper is presented in the National Workshop on Fodder Cultivation and Artificial Insemination; Organized by Palli Karma-Shahayak Foundation, PKSF Auditorium, Dhaka, Bangladesh.

Huque KS, Swapon KF, Asma S (2006). Livestock for food security- ways for achieving goals. Proceedings of the $7^{\text {th }}$ Annual Scientific Conference of Chittagong Veterinary and Animal Science University, Khulsi, Chittagong. P. 202.

Huque KS, Amanullah SM (2009). State of art of cattle fattening in Bangladesh: the paper was presented in the regional workshop organized by IC-Shakti, an NGO during June 21 to 25, 2009 in the Rural Development Academy (RDA), Bogra, Bangladesh.

Huque KS (2005). Development of smallholder dairy in Bangladesh; Workshop on "Training Programme for the Small Scale Dairy Sector Project" of the Govt. of the Peoples' Republic of Bangladesh and Food and Agriculture Organization of the United Nations held on December 26, 2005 at Hotel Sheraton, Dhaka, Bangladesh.

Huque KS, Chowdhury SA (1997). Study on the supplementing effects or feeding systems of molasses and urea on methane and microbial nitrogen production in the rumen and growth performances of bulls fed a straw diet. Asian Austral-Asian Journal of Animal Science, 10: 35-46.

Khan SJ (2010). Study on growth promoters used for cattle fattening in Bangladesh, MSc thesis, Department of Animal Nutrition, Bangladesh Agricultural University, Mymensingh, Bangladesh.
Makkar HPS (2013). Sustainable increase in ruminant productivity through efficient utilisation of feed resources with a focus on Bangladesh, The paper was presented in a seminar on Livestock feeding and nutritionglobal perspective and options for Bangladesh, organized by the Bangladesh Livestock Research Institute on September 26, 2013 at Savar, Dhaka, Bangladesh.

Makkar HPS, Becker K (1996). Nutritional value and anti-nutritional components of whole and ethanol extracted Moringa oleifera leaves. Animal Feed Science and Technology, 63: 211-228.

Mendieta B, Reyes N, Rodriguez R (2007). Successful experiences on the use of Moringa oleifera in animal feeding (http://redmarango.una.edu.ni/documento s/20-Bryan-Moringa-pres-Vietnam-finalversion.pdf).

Sanchez NR., Sporndly E, Ledin I (2006). Effect of feeding different levels of foliage of Moringa oleifera to creole dairy cows on intake, digestibility, milk production and composition. Livestock Science, 101: 2431.

Steinfeld H, Gerber P, Wassenaar T, Castel V, Rosales CM, de Haan C (2006). Livestock long shadow: environmental issues and options, Rome, Italy: FAO.

Sultana N, Huque KS, Alimonand AR, Hossain SMJ (2012). Study on Moringa Oliefera foliage as a feed for growing male goats; In the proceedings of the Annual Research Review Workshop, Bangladesh Livestock Research Institute, Savar, Dhaka, Bangladesh.

Sultana N, Huque S, KS, Razzak A (2012). Study on the influence of Moringa oleifera foliage as substitute to conventional concentrate in growing goats. In the proceedings of the Annual Research Review Workshop, Bangladesh Livestock Research Institute, Savar, Dhaka, Bangladesh.

Thronton PK (2010). Livestock production: recent trends, future prospects. Hil. Trans. R. Soc. B 27 September 2010, 365: 2853-2867.

Zarkadas CG, Yu Z, Burrows VD (1995). Protein quality of three new Canadian-developed naked oat cultivars using amino acid compositional data. Journal of Agricultural and Food Chemistry, 43: 415-421. 